\title{
Optimization of spray drying process parameters for tucupi powder using the response surface methodology
}

\author{
Flavia Cristina Seabra Pires ${ }^{1} \cdot$ Rosinelson da Silva Pena $^{1,2}$
}

Revised: 7 June 2017/ Accepted: 10 August 2017/Published online: 28 August 2017

(C) Association of Food Scientists \& Technologists (India) 2017

\begin{abstract}
A completely randomized $2^{3}$ factorial experimental design was used to optimize the process parameters for obtaining tucupi powder through spray drying. The effects of the process variables [inlet air temperature (IT), feed flow rate (FR), and maltodextrin concentration (MD)] on the product properties [moisture, water activity $\left(\mathrm{a}_{\mathrm{w}}\right)$, hygroscopicity, water absorption index (WAI), water solubility index (WSI), total color difference $\left(\Delta \mathrm{E}^{*}\right)$, and $\beta$ carotene content] were studied using the response surface methodology (RSM) and linear perturbation plot. In addition, scanning electron microscopy (SEM) images were obtained of the product. According to ANOVA and the regression coefficients $\left(\mathrm{R}^{2}>0.90\right)$, the RSM models were significant and IT was the variable with the greatest impact on most of the responses. SEM shows that the powders obtained with higher IT and MD and lower FR were more uniform, with smooth and intact surfaces. The optimal conditions estimated for the process were IT at $214{ }^{\circ} \mathrm{C}$, FR at $8.67 \mathrm{~mL} / \mathrm{min}$, and $\mathrm{MD}$ at $27 \%$. Under those conditions, the product's minimum values of moisture $(9.56 \mathrm{~g} / 100 \mathrm{~g})$, $\mathrm{a}_{\mathrm{w}}(0.101)$, hygroscopicity (37.45\% d.b.), and $\Delta \mathrm{E}^{*}(17.05)$ and maximum values of WAI $(6.68 \mathrm{~g} / \mathrm{g}$ d.b.), WSI $(84.77 \%)$, and $\beta$-carotene $(13.72 \mu \mathrm{g} / \mathrm{g})$ were estimated.
\end{abstract}

Rosinelson da Silva Pena

rspena@ufpa.br

1 Graduate Program in Food Science and Technology, Technology Institute, Federal University of Pará (UFPA), Belém, PA 66075-110, Brazil

2 Faculty of Food Engineering, Institute of Technology, Federal University of Pará (UFPA), Rua Augusto Côrrea, 01, Belém, PA 66075-110, Brazil
Keywords Manihot esculenta $\cdot$ Nebulization · Microencapsulation · Desirability · Morphology · $\beta$-Carotene

\section{Introduction}

Tucupi is a highly appreciated fermented sauce in the Brazilian Amazon, where it is produced through the fermentation of the liquid residue-cassava wastewater, known locally as manipueira-during the flour production process (Cassoni and Cereda 2011; Chisté and Cohen 2011). It is an artisanal product originated from the native populations and typical of the north of Brazil, where it is consumed as sauces with pepper or as an ingredient of several regional dishes. However, the exotic sensory properties of this product have driven its use in culinary formulations in different countries worldwide according to gastronomic reports.

Since tucupi comprises basically water $(\approx 95 \%)$, with a soluble-solids fraction and another that remains in suspension, one alternative for industrial processing and preservation of the product is flash drying methods, such as spray drying (Obon et al. 2009). Since the tucupi powder obtained is derived from an agricultural by-product, it has high added value, which creates an agro-industrial outlook for the development of new products (Homma et al. 2014). Furthermore, since it is a low-moisture product, tucupi powder is more shelf stable, besides being easier to use and more economic to package and store (Sagar and Suresh Kumar 2010).

Spray drying is the process most commonly used by the food industry to transform suspensions into powders. The technique is a flexible and continuous process with low operational cost and good yield that produces particles with 
excellent properties such as small size, good solubility, and high stability (Desai and Park 2005; Obon et al. 2009). The high drying rates and short permanence of the product inside the drying chamber observed in the spray drying process lowers thermal damage to thermosensitive compounds in the product, which favors the fixation of nutrients, color, and flavor. Moreover, products obtained by spray drying have very low moisture and water activity, which are the main parameters that define process performance (Kha et al. 2010). Those characteristics are directly related to the operational conditions such as inlet air temperature and product feed flow rate (Rodríguez-Jimenes et al. 2014). In addition, the use of carrier materials, such as maltodextrin, can be an effective means of protecting the compounds in the dry product and, thus, minimize issues with tackiness and clumping during storage (Ré 1998).

The production of tucupi powder by spray drying requires some process parameters to be adjusted so that a product with desirable characteristics can be obtained. In this context, the response surface methodology (RSM) has proved to be an efficient method to optimize such processes (Balasubramani et al. 2013; Chen et al. 2014). RSM can be applied in the design, improvement, and development of new products (Bas and Boyaci 2007).

In face of that, this study aimed to establish optimized process conditions for tucupi powder obtention by spray drying based on product quality characteristics using RSM. To that end, the study assessed the effects of process variables (IT, FR and MD) on product properties (moisture, water activity- $\mathrm{a}_{\mathrm{w}}$, hygroscopicity, water absorption index-WAI, water solubility index-WSI, total color difference $-\Delta \mathrm{E}^{*}$, and $\beta$-carotene content).

\section{Materials and methods}

\section{Raw materials}

The tucupi used in the research was obtained from a supplier in the city of Acará (Pará, Brazil) $\left(01^{\circ} 57^{\prime} 39^{\prime \prime} \mathrm{S}\right.$ and $48^{\circ} 11^{\prime} 48^{\prime \prime} \mathrm{W}$ ). The trials used $50 \mathrm{~L}$ of the product free of any seasonings. Maltodextrin 20DE (Cargill Agrícola S.A., Brazil) was used as carrier agent.

\section{Sample preparation}

Before drying, the tucupi containing $94.55 \pm 0.05 \mathrm{~g} / 100 \mathrm{~g}$ moisture, $0.96 \pm 0.07 \mathrm{~g} / 100 \mathrm{~g}$ proteins, $0.16 \pm 0.01 \mathrm{~g} /$ $100 \mathrm{~g}$ lipids, $0.68 \pm 0.02 \mathrm{~g} / 100 \mathrm{~g}$ ashes, $1.65 \pm 0.08 \mathrm{~g} /$ $100 \mathrm{~g}$ starch, $0.28 \pm 0.02 \mathrm{~g} / 100 \mathrm{~g}$ total sugars, and $4.19 \pm 0.09 \mu \mathrm{g} / \mathrm{g} \beta$-carotene equivalent was concentrated at $70{ }^{\circ} \mathrm{C}$ in a vacuum rotary evaporator (MA 120/1/E, Marconi, Brazil) down to $25 \%$ total solids. This concentration was defined in preliminary assays, which showed that, at $70{ }^{\circ} \mathrm{C}$, the losses of the characteristic properties of the product were minimum and process time was not excessively long.

\section{Spray drying}

A mini spray dryer (B-290, BÜCHI Labortechnik AG, Flawil, Switzerland) equipped with a control panel, electric heating element, peristaltic pump, two fluid nozzles, drying chamber, and cyclone made of thick clear class was used in the tucupi drying assay. For the drying process, the environment air was heated with an electric heating element and blown in parallel flow to the atomized liquid inside the drying chamber at $35 \mathrm{~m}^{3} / \mathrm{h}$. In all assays, the total solids content of the feeding mix (concentrated tucupi and maltodextrin) was set to $25 \%(\mathrm{w} / \mathrm{w})$ and temperature, to $25 \pm 1{ }^{\circ} \mathrm{C}$. The maltodextrin content added to the concentrated tucupi was calculated based on the dry matter and the blend was stirred for $15 \mathrm{~min}$ in a 235-1 stirrer (Quimis, Brazil) for complete dissolution of the carrier agent. The drying chamber was fed by a two-nozzle peristaltic pump (feeding nozzle internal diameter of $0.7 \mathrm{~mm}$ ) driven by compressed air ( 8 bar) and controlled by a flow meter. The powdered samples were collected in a vessel at the base of the cyclone, placed in airtight glass flasks, and stored at room temperature $\left(\approx 25^{\circ} \mathrm{C}\right)$ until the analyses.

\section{Experimental design and statistical analysis}

Inlet air temperature (IT, $\left.\mathrm{X}_{1}\right)$, feed flow rate $\left(\mathrm{FR}, \mathrm{X}_{2}\right)$, and maltodextrin concentration ( $\mathrm{MD}, \mathrm{X}_{3}$ ) were selected as independent variables for the tucupi spray drying process based on preliminary assays. The effects of those variables on the responses were analyzed by the response surface methodology (RSM). The study employed a $2^{3}$ rotatable central composite design with eight factorial points (levels \pm 1 ), six axial points (one variable at level $\pm \alpha$ and two at level 0 ), and three replicates in the central point (level 0) for a total of 17 runs (first four columns in Table 1). The response variables $\left(\mathrm{Y}_{\mathrm{i}}\right)$ were: moisture $\left(\mathrm{Y}_{1}\right)$, $\mathrm{a}_{\mathrm{w}}\left(\mathrm{Y}_{2}\right)$, hygroscopicity $\left(\mathrm{Y}_{3}\right)$, WAI $\left(\mathrm{Y}_{4}\right)$, WSI $\left(\mathrm{Y}_{5}\right), \Delta \mathrm{E}^{*}$ $\left(\mathrm{Y}_{6}\right)$, and $\beta$-carotene content $\left(\mathrm{Y}_{7}\right)$. The runs were carried out randomly to minimize the effect of unexpected variability due to external factors. A second-order polynomial regression model was used to predict the responses $\mathrm{Yi}\left(\mathrm{Y}_{1-}\right.$ $\mathrm{Y}_{7}$ ) as described by the following equation:

$$
\begin{aligned}
\mathrm{Y}_{\mathrm{i}}= & \beta_{0}+\beta_{1} \mathrm{IT}+\beta_{2} \mathrm{FR}+\beta_{3} \mathrm{MD}+\beta_{11} \mathrm{IT}^{2} \\
& +\beta_{22} \mathrm{FR}^{2}+\beta_{33} \mathrm{MD}^{2}+\beta_{12} \mathrm{IT}(\mathrm{FR}) \\
& +\beta_{13} \mathrm{IT}(\mathrm{MD})+\beta_{23} \mathrm{FR}(\mathrm{MD})
\end{aligned}
$$




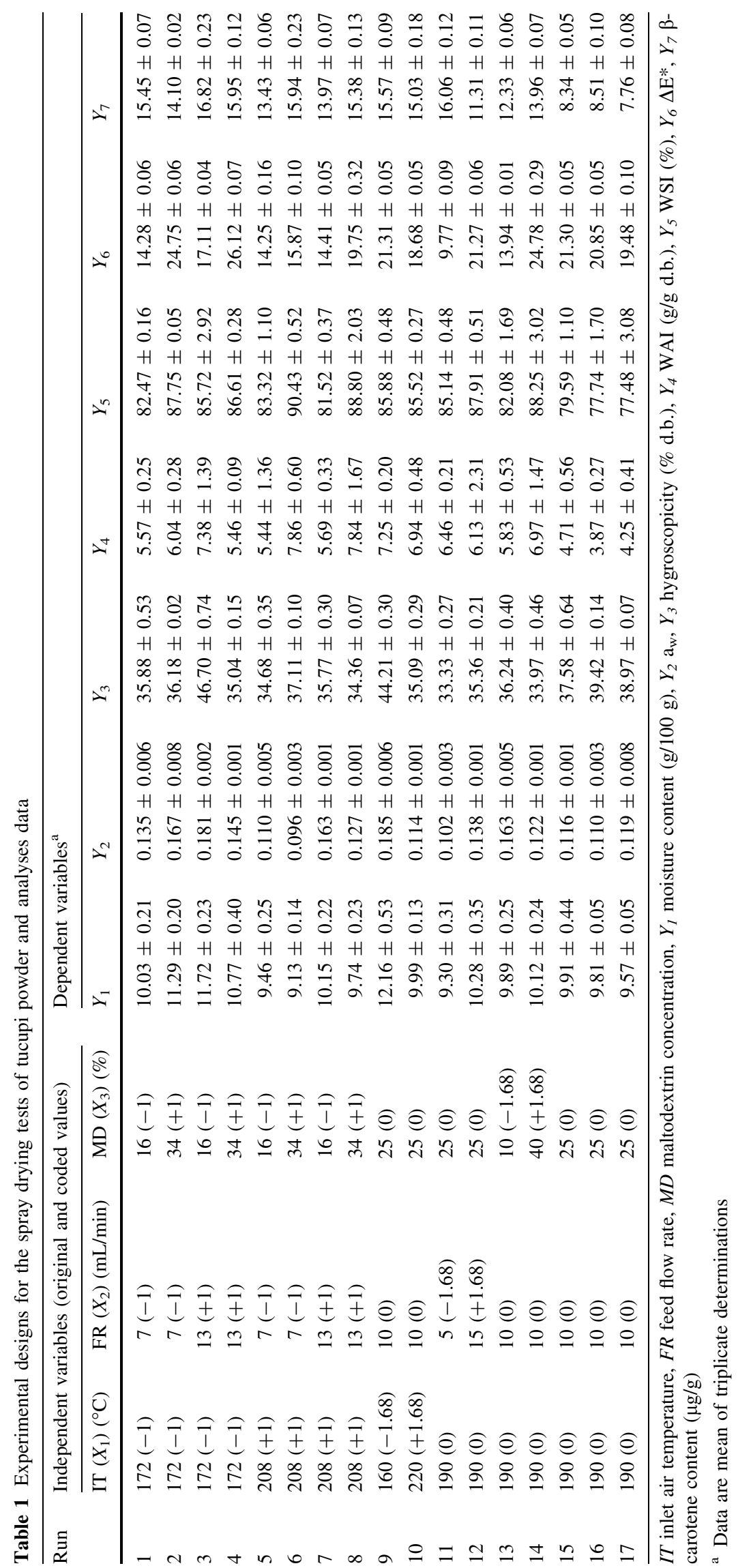


were $\beta_{0}$ represents the constant term; $\beta_{1}, \beta_{2}$, and $\beta_{3}$, the linear coefficients; $\beta_{12}, \beta_{13}$, and $\beta_{23}$, the interaction coefficients; and $\beta_{11}, \beta_{22}$, and $\beta_{33}$, the quadratic coefficients.

Lack-of-fit was used to assess the fits of the mathematical models. Model fit was assessed by the coefficient of determination $\mathrm{R}^{2}$, analysis of variance (ANOVA), coefficient of variation (CV), adeq-precision, PRESS, Adj$\mathrm{R}^{2}$ and Pred- $\mathrm{R}^{2}$, which are statistically important values for the use of predictive models in later calculations (Noordin et al. 2004). The optimal levels of the independent variables were analyzed using the desirability function method. A value of $p \leq 0.05$ was considered statistically significant. The response analyses, response surfaces, linear perturbation plots and desirability function were obtained using the software Statistica Kernel Release 7.1 (StatSoft Inc. 2006, Tulsa, OK, USA).

\section{Moisture content}

Powder moisture was determined in an air-circulation oven at $105{ }^{\circ} \mathrm{C}$ according to AOAC (1997) method no. 926.12. The values were expressed as $\mathrm{g}$ of water per $100 \mathrm{~g}$ of powder $(\mathrm{w} / \mathrm{w})$.

\section{Water activity}

Powder water activity $\left(\mathrm{a}_{\mathrm{w}}\right)$ was determined at $25 \pm 1{ }^{\circ} \mathrm{C}$ in a water activity meter (Aqualab series 3TE, Decagon Devices Inc., WA, USA).

\section{Hygroscopicity}

In order to determine hygroscopicity, $1 \mathrm{~g}$ of powder sample was weighed in a beaker and placed in a desiccator containing a saturated $\mathrm{NaCl}$ solution (76\% relative humidity) at $25 \pm 1{ }^{\circ} \mathrm{C}$. After 10 days, the sample was weighed again to calculate hygroscopicity, expressed as $\mathrm{g}$ of water per g of dry solids (d.b.) (Cai and Corke 2000).

\section{Water absorption index (WAI) and water solubility index (WSI)}

WAI and WSI were determined using the method described by Anderson et al. (1969). To that end, $1 \mathrm{~g}$ of powder was added to $12 \mathrm{~mL}$ of water at $25{ }^{\circ} \mathrm{C}$ in a $15 \mathrm{~mL}$ centrifugation tube. The mix was stirred intermittently for $30 \mathrm{~min}$ and centrifuged for $10 \mathrm{~min}$ at $704 \times g$. The supernatant was carefully transferred onto a Petri dish and dried in a vacuum oven at $60{ }^{\circ} \mathrm{C}$ and $25 \mathrm{mmHg}$. The WAI was expressed as mass of the centrifugation residue $(\mathrm{g})$ per mass of solids in the centrifugation residue $(\mathrm{g})$, while the
WSI was expressed as mass of the evaporation residue (g) per $100 \mathrm{~g}$ of sample (d.b.).

\section{Total color difference value $\left(\Delta \mathrm{E}^{*}\right)$}

The total color difference $\left(\Delta \mathrm{E}^{*}\right)$ between tucupi powder and in natura tucupi was calculated based on the instrumental color parameters determined by a colorimeter (CR400 Konica, Minolta Co., Osaka, Japan) calibrated with a white plate according to the parameters of the International Commission on Illumination (CIE). The $\Delta \mathrm{E}^{*}$ value was calculated by the following equation:

$\Delta \mathrm{E}^{*}=\sqrt{\left(\Delta \mathrm{L}^{*}\right)^{2}+\left(\Delta \mathrm{a}^{*}\right)^{2}+\left(\Delta \mathrm{b}^{*}\right)^{2}}$

where $\mathrm{L}^{*}$ defines luminosity $\left(\mathrm{L}^{*}=0\right.$ black; $\mathrm{L}^{*}=100$ white) and $\mathrm{a}^{*}$ and $\mathrm{b}^{*}$ are responsible for chromaticity $\left(+a^{*}=\right.$ red and $-a^{*}=$ green $/+b^{*}=$ yellow and $-b^{*}=$ blue).

\section{$\beta$-carotene content}

The $\beta$-carotene content was determined by reading the sample absorbance in a spectrophotometer (Thermo 10UV, Genesys, USA) at $450 \mathrm{~nm}$. The acetone and petroleum ether were used as solvents for the extraction of $\beta$-carotene, according to Rodriguez-Amaya and Kimura (2004). The values were expressed in $\mathrm{mg}$ of $\beta$-carotene equivalent per $\mathrm{g}$ of tucupi in the sample $(\mathrm{w} / \mathrm{w})$.

\section{Scanning electron microscopy}

Powder morphology was assessed based on electromicrographies obtained by scanning electron microscopy (SEM). For the SEM procedure, a small amount of sample was sprinkled onto double-sided adhesive tape mounted on a base $1 \mathrm{~cm}$ in diameter and $1 \mathrm{~cm}$ in height. The sample was gold plated under vacuum to provide a reflective surface for the electron beam and reading was carried out in a scanning electron microscope (MEV 1430 LEO-ZEISS, Carl Zeiss Ltda., Germany, BW).

\section{Results and discussion}

\section{Model fit}

The values of moisture, $\mathrm{a}_{\mathrm{w}}$, hygroscopicity, WAI, WSI, $\Delta \mathrm{E}^{*}$, and $\beta$-carotene of the tucupi powder obtained in each run of the experimental design are presented in Table 1 (columns five to 11). In turn, the results of ANOVA, significance test of the regression model, correlation coefficients, and lack-of-fit are presented in Table 2. According 


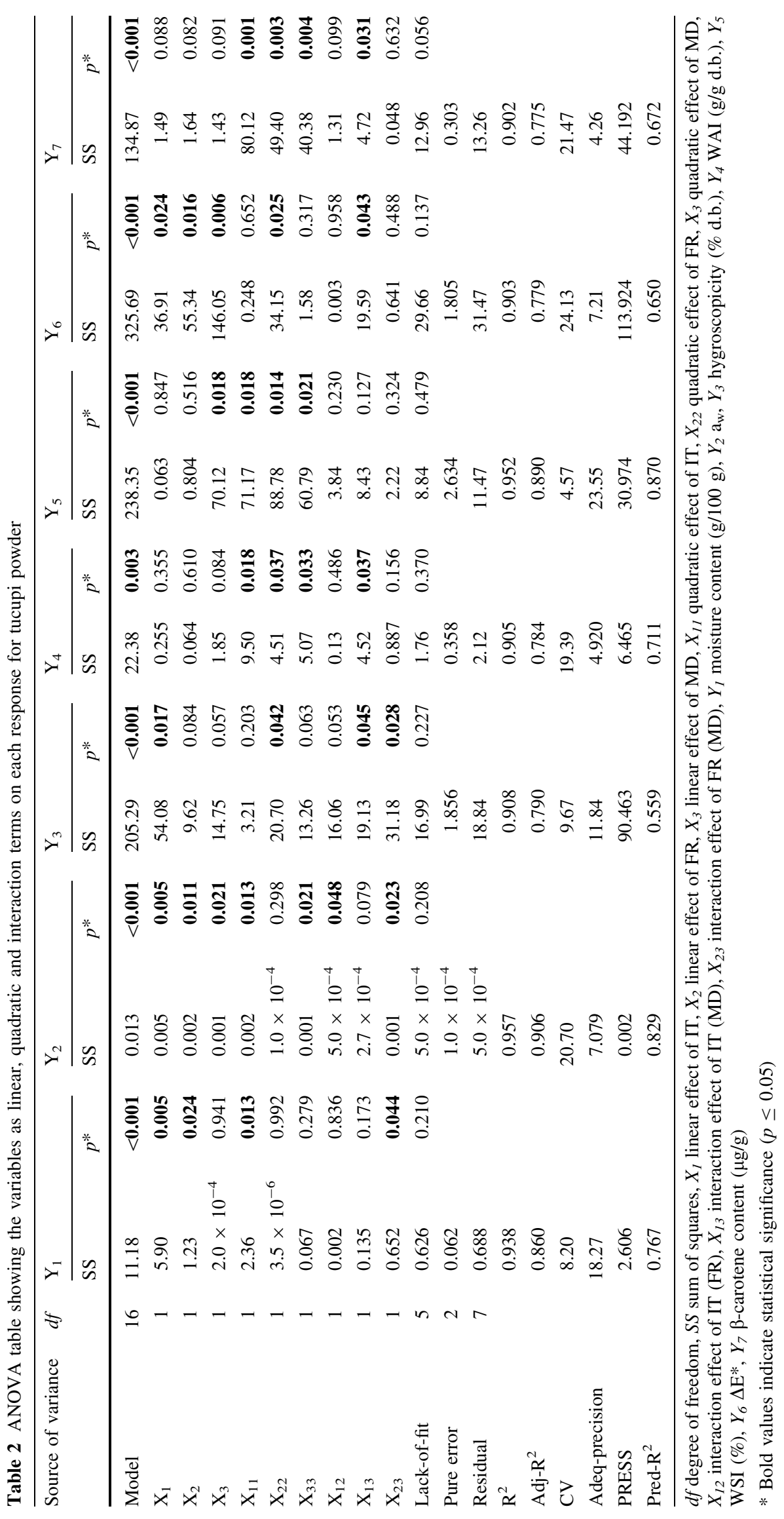


to the ANOVA results and values, the surface response models were statistically significant $(p \leq 0.05)$ for all regression equations. The values of $\mathrm{R}^{2}>0.90$ for all variables studied reveal that the experimental data were well represented by the second-degree polynomial equations, whose regression coefficients are presented in Table 3. The lack-of-fit, which measures model fit, did not yield a significant $p$ value $(p \leq 0.05)$, which suggests the regression models represented the variations in the responses studied with good reproducibility (Table 2).

As an additional statistical parameter used to assess model fit, $\mathrm{CV}$ values were calculated. High $\mathrm{CV}$ values indicate higher mean deviations and, in that case, the reliability of the model is lower (Balasubramani et al. 2013). However, according to Granato and Calado (2014), only CV values above $30 \%$ indicate data problems and in these cases, the experiments must be repeated. In this context, the models that estimated the responses of moisture, hygroscopicity, and WSI were those that yielded the lowest CV values and, consequently, the lowest mean deviations.

Adeq-precision measures the difference between the response predicted (or expected) and the associated error (a value higher than four is desirable; Noordin et al. 2004). The values of that parameter were above four for all responses studied, which suggests adequate discrimination by the individual models and that they can be used in the experimental domain (Montgomery 2001). The PRESS value is a measure of how a particular model fits each point in the design, while Pred- $\mathrm{R}^{2}$ value is a measure of the model's predictive ability. In turn, $\operatorname{Adj}-\mathrm{R}^{2}$ is a measure of the amount of variation around the mean adjusted for the number of model parameters. Pred- $\mathrm{R}^{2}$ value must be close to the Adj- $\mathrm{R}^{2}$ and the difference between Adj- $\mathrm{R}^{2}$ and Pre-
$\mathrm{R}^{2}$ must be less than 0.2 for practical purposes (Myers and Montgomery 2002). Thus, according to these parameters, the best fit observed were for the moisture content, $a_{w}$, WAI and WSI responses.

\section{Moisture content}

The moisture of the powders obtained under different experimental conditions ranged from 9.13 to $12.16 \mathrm{~g} / 100 \mathrm{~g}$ (Table 1). Moisture is one of the main controls in drying processes since this property may impact product stability as well as influence its application and acceptability (Barbosa-Cánovas and Juliano 2005). According to the model, the linear effects of IT $\left(\mathrm{X}_{1}\right)$ and FR $\left(\mathrm{X}_{2}\right)$, quadratic effects of IT $\left(\mathrm{X}_{11}\right)$, and of the interaction between FR and MD $\left(\mathrm{X}_{23}\right)$ were statistically significant $(p \leq 0.05)$ and IT (linear) was the factor with the greatest influence on the moisture response of tucupi powder (Table 2). Product moisture decreased as IT increased up to $200{ }^{\circ} \mathrm{C}$ (Fig. 1a), which can be attributed to the increase in heat transfer rate to the particles, leading to higher driving force for water removal (Chen et al. 2014). After this point, the moisture content increased due to the impermeable crust formation on the particle surface, which decreased the drying rate and prevented the output of water by convection (Marques et al. 2014a). On the other hand, higher FR values led to higher product moisture (Fig. 1b). The increase in FR shortens the time of contact between product droplets and the drying air, which limits heat transfer and, consequently, mass transfer (Kurozawa et al. 2009). These effects are evidenced in the linear perturbation plot (Fig. 1c), where IT has a negative effect and FR has a positive effect on the moisture content of tucupi powder, while MD shows no significant effect. Although MD factor had not presented an

Table 3 Regression equation coefficients for response parameters of tucupi powder

\begin{tabular}{lllllrrr}
\hline Regression coefficient & \multicolumn{1}{l}{$\mathrm{Y}_{1}$} & $\mathrm{Y}_{2}$ & $\mathrm{Y}_{3}$ & $\mathrm{Y}_{4}$ & $\mathrm{Y}_{5}$ & $\mathrm{Y}_{6}$ & $\mathrm{Y}_{7}$ \\
\hline$\beta_{0}$ & 61.815 & 1.807 & 73.266 & 131.990 & 404.328 & -61.062 \\
$\beta_{1}$ & -0.561 & -0.016 & -0.719 & -1.174 & -3.009 & 0.329 \\
$\beta_{2}$ & 0.311 & -0.017 & 10.144 & -0.653 & -3.304 & -3.225 \\
$\beta_{3}$ & 0.212 & $3.60 \times 10^{-3}$ & -0.522 & -1.137 & -2.208 & 2.396 \\
$\beta_{11}$ & $1.42 \times 10^{-3}$ & $3.90 \times 10^{-5}$ & $1.66 \times 10^{-3}$ & $2.90 \times 10^{-3}$ & $7.80 \times 10^{-3}$ & $-5.00 \times 10^{-4}$ & -3.327 \\
$\beta_{22}$ & $-1.10 \times 10^{-4}$ & $2.35 \times 10^{-4}$ & -0.152 & 0.071 & 0.316 & -0.196 \\
$\beta_{33}$ & $9.40 \times 10^{-4}$ & $1.26 \times 10^{-4}$ & -0.014 & $8.40 \times 10^{-3}$ & 0.029 & $-4.70 \times 10^{-3}$ \\
$\beta_{12}$ & $3.00 \times 10^{-4}$ & $1.39 \times 10^{-4}$ & -0.026 & $-2.30 \times 10^{-3}$ & -0.013 & 0.024 \\
$\beta_{13}$ & $-8.10 \times 10^{-4}$ & $-3.50 \times 10^{-5}$ & 0.010 & $4.60 \times 10^{-3}$ & $6.30 \times 10^{-3}$ & -0.010 \\
$\beta_{23}$ & -0.011 & $-4.17 \times 10^{-4}$ & -0.073 & -0.012 & -0.020 & $0.00 \times 10^{-4}$ \\
\hline
\end{tabular}

The coefficients are related to the original values of factors; $\beta_{0}$ constant term, $\beta_{1}$ linear coefficient of IT, $\beta_{2}$ linear coefficient of FR, $\beta_{3}$ linear coefficient of $\mathrm{MD}, \beta_{11}$ quadratic coefficient of IT, $\beta_{22}$ quadratic coefficient of FR, $\beta_{33}$ quadratic coefficient of MD, $\beta_{12}$ interaction coefficient of IT (FR), $\beta_{13}$ interaction coefficient of IT (MD), and $\beta_{23}$ interaction coefficient of FR (MD), $Y_{1}$ moisture content (g/100 g), $Y_{2} \mathrm{a}_{\mathrm{w}}, Y_{3}$ hygroscopicity (\% d.b.), $Y_{4}$ WAI (g/g d.b.), $Y_{5}$ WSI $(\%), Y_{6} \Delta \mathrm{E}^{*}, Y_{7} \beta$-carotene content $(\mu \mathrm{g} / \mathrm{g})$ 

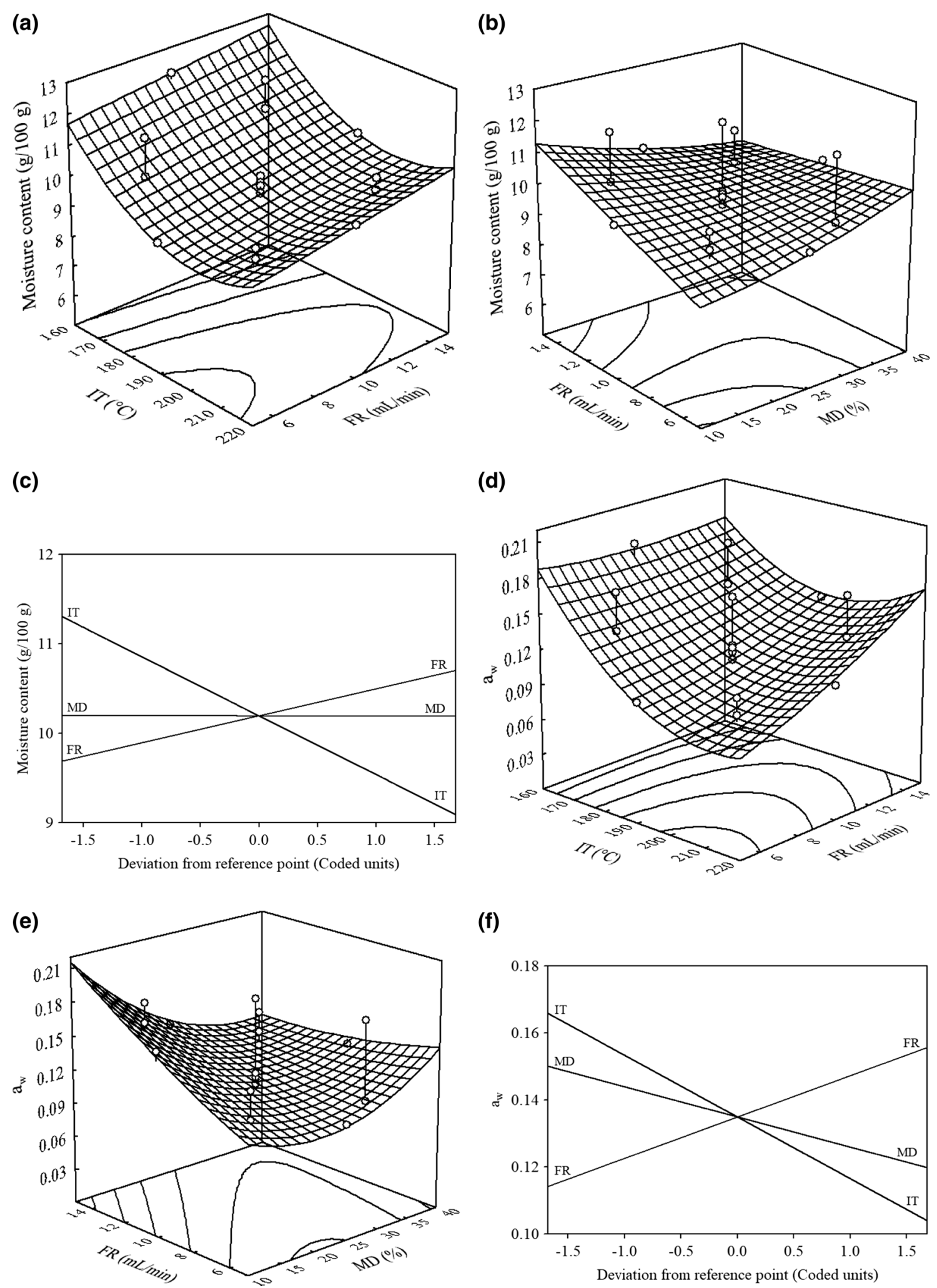

(f)

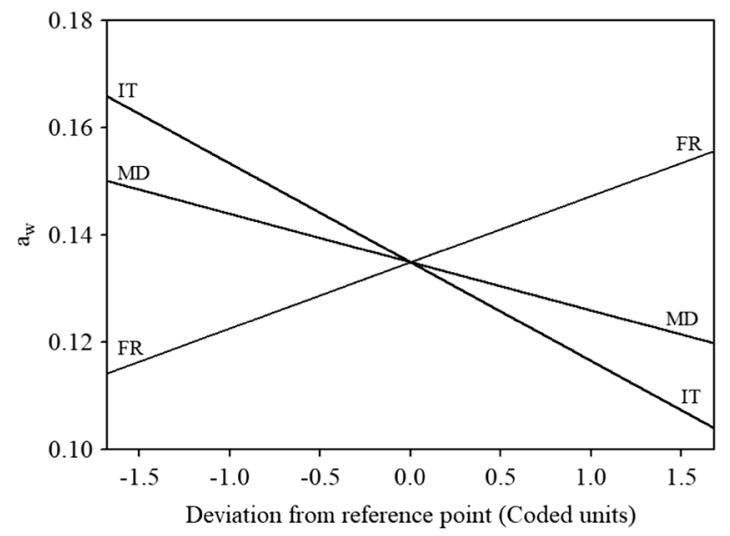

Fig. 1 Responses surfaces and linear perturbation plots for the effects of variables on the moisture content (a-c), $a_{w}(\mathbf{d}-\mathbf{f})$ and hygroscopicity $(\mathbf{g}-$ i). The value of the third factor was fixed at $190{ }^{\circ} \mathrm{C}$ for IT, $10 \mathrm{~mL} / \mathrm{min}$ for $\mathrm{FR}$ and $25 \%$ for MD 

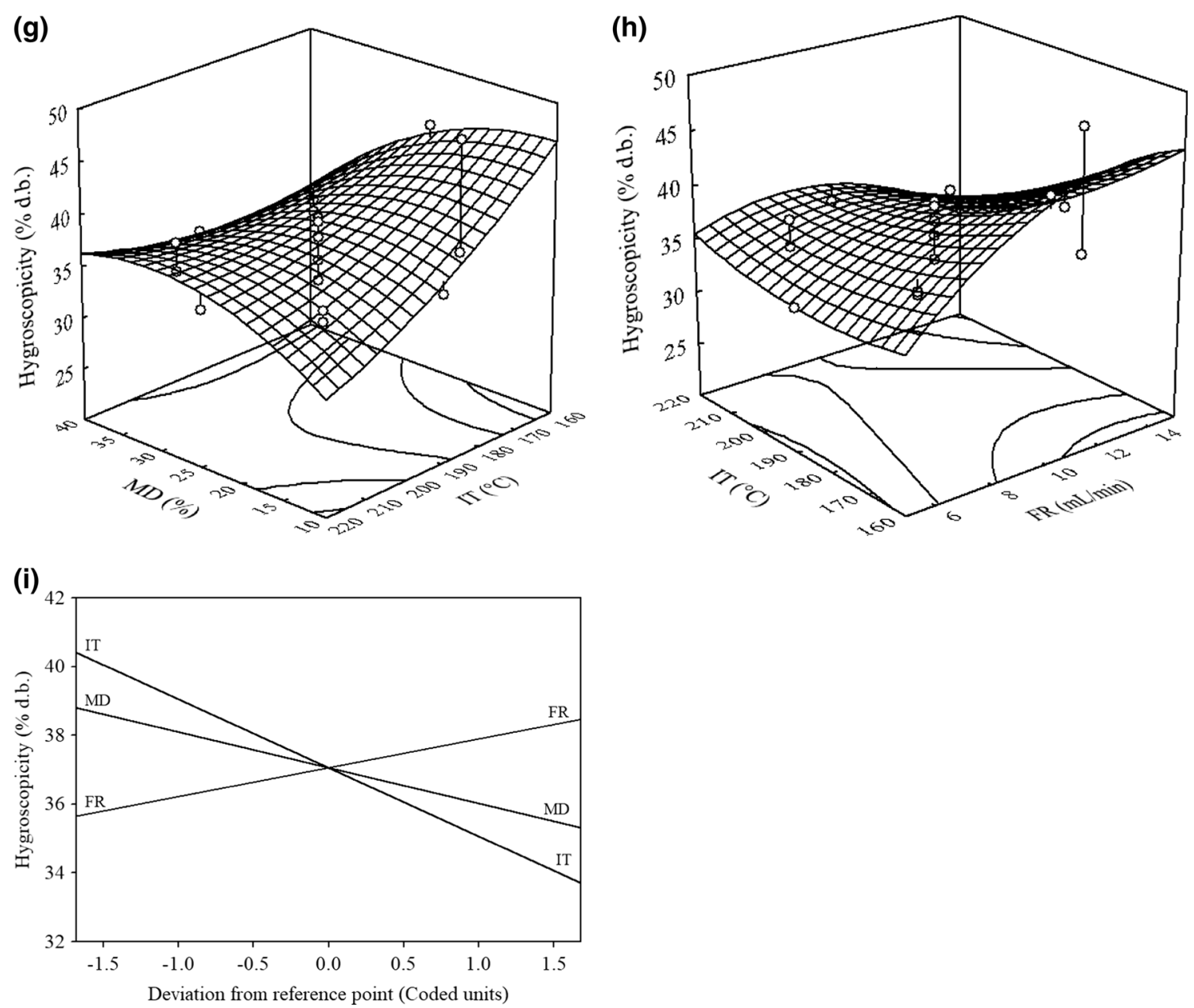

Fig. 1 continued

isolated effect on the moisture, the interaction between FR and MD showed that an increase of these parameters promoted the reduction of this response (Fig. 1b). This behavior is attributed to the fact that an increase in the maltodextrin content decreases the superficial stickiness caused by low-molecular-weight sugars, which favors the outflow of water (Adhikari et al. 2003, 2004).

\section{Water activity $\left(\mathbf{a}_{\mathrm{w}}\right)$}

The $\mathrm{a}_{\mathrm{w}}$ values of tucupi powder between 0.096 and 0.185 (Table 1) suggest that all experimental conditions studied ensure a product with microbiological stability $\left(a_{w}<0.6\right)$ (Fennema 1996). Moreover, under those $a_{w}$ conditions, the product will be less susceptible to both chemical and enzymatic spoilage reactions if stored properly in packaging with low water vapor permeability (Nelson and Cox 2012). In the case of $a_{w}$, the ANOVA results (Table 2) showed that this response was statistically impacted $(p \leq 0.05)$ by the linear effects of IT $\left(\mathrm{X}_{1}\right), \mathrm{FR}\left(\mathrm{X}_{2}\right)$, and $\mathrm{MD}\left(\mathrm{X}_{3}\right)$; quadratic effects of IT $\left(\mathrm{X}_{11}\right)$ and $\mathrm{MD}\left(\mathrm{X}_{33}\right)$; and of the interactions between IT and FR $\left(\mathrm{X}_{12}\right)$, and FR and MD $\left(\mathrm{X}_{23}\right)$. Again, IT (linear) was the factor with the greatest impact. Following the same overall trend as moisture, the response surfaces show that increasing IT up to $200{ }^{\circ} \mathrm{C}$ (Fig. 1d), increasing MD up to $20 \%$, and decreasing FR (Fig. 1e) led to lower $\mathrm{a}_{\mathrm{w}}$ in the tucupi powder. These tendencies can be observed in the linear perturbation plot (Fig. 1f). The limitation in $a_{w}$ reduction for higher MD values (Fig. 1e) can be attributed to the reduction in mobility of water molecules through the maltodextrin molecules, which hinders the diffusion of water molecules. Similar behavior was observed by Adhikari et al. (2004) for foods rich in sugars and acids, such as the obtained tucupi powder.

\section{Hygroscopicity}

Under the experimental conditions studied, hygroscopicity of the tucupi powder obtained ranged from 33.33 to $46.70 \%$ d.b. Those results suggest that the presence of lowmolecular-weight sugars and organic acids in the product 
favored hygroscopicity, even when MD was used at $40 \%$. Those types of solutes are responsible for strong interactions with water molecules as a function of the polar terminals present in their molecules (Jaya and Das 2004). For the hygroscopicity response, the linear effect of IT $\left(\mathrm{X}_{1}\right)$ was also the factor with the greatest impact, while quadratic effects were also observed for FR $\left(\mathrm{X}_{22}\right)$ and the interactions between IT an MD $\left(\mathrm{X}_{13}\right)$, and $\mathrm{FR}$ and $\mathrm{MD}$ $\left(\mathrm{X}_{23}\right)(p \leq 0.05)$ (Table 2). Hygroscopicity dropped with higher IT and MD values at $20 \%$ onwards (Fig. 1g) and as FR values decreased to below $10 \mathrm{~mL} / \mathrm{min}$ (Fig. 1h). The linear perturbation plot showed in Fig. 1i confirms these behaviors. The behavior observed can be attributed to a possible increase in the product's glass transition temperature since, as moisture drops (higher IT), glass transition temperature increases and the characteristics of powdered products may change, thus decreasing hygroscopicity and producing more stable particles during processing (Bhandari and Hartel 2005). In addition, the reduction in product hygroscopicity as MD increases is related to the characteristic of the carrier agent used, which is little hygroscopic. This behavior reinforces potential use of maltodextrin as a carrier agent for tucupi powder obtained by spray drying, which provides greater protection against moisture adsorption by the product (Yousefi et al. 2011).

\section{Water absorption index (WAI) and water solubility index (WSI)}

WAI (3.87-7.86 g/g d.b.) and WSI (77.48-90.43\%) values of tucupi powder were considered satisfactory since they show that most of the solid elements in the powder obtained under the experimental conditions were easily soluble in water. Those indices are related to the amount of soluble solids present in the product as a function of the solubilization of starches, sugars, proteins, fibers, and even maltodextrin (Augusto-Ruiz et al. 2003). According to Table 2, the quadratic effects of IT $\left(\mathrm{X}_{11}\right), \mathrm{FR}\left(\mathrm{X}_{22}\right)$, and MD $\left(\mathrm{X}_{33}\right)$ were statistically significant $(p \leq 0.05)$ both for WAI and WSI responses. A linear effect of MD $\left(\mathrm{X}_{3}\right)$ for WSI and of the interaction between IT and MD $\left(\mathrm{X}_{13}\right)$ was also observed for WAI. The quadratic effects indicated minimum values for both responses (WAI and WSI) at intermediate levels of the variables (Fig. $2 a, b, d, e$ ). The highest response values were observed for IT $>190{ }^{\circ} \mathrm{C}$ and $\mathrm{MD}>20 \%$ (Fig. 2a, d). For the FR variable, values either below or above $10 \mathrm{~mL} / \mathrm{min}$ indicated the same increase in WAI (Fig. 2b) and WSI (Fig. 2e). In turn, the linear perturbation plots shows positive effects of IT, FR and MD, both to WAI (Fig. 2c) and WSI (Fig. 2f) of tucupi powder. The increase in IT leads the formation of a porous layer on the surface of the powder particles, thus, it increasing wettability and dissolution, which justifies the increase of WSI (Fig. 2d, e; Chegini and Ghobadian 2005). The increase in WAI with MD can be attributed to the chemical structure of the carrier agent maltodextrin 20DE. MD has a large number of hydroxyl groups, which absorb water molecules more easily (Tonon et al. 2009). In turn, the increase in WSI caused by the increase in MD is justified by the high solubility of this carrier agent (Chegini and Ghobadian 2005).

\section{Total color difference $\left(\Delta E^{*}\right)$}

The $\Delta \mathrm{E}^{*}$ values observed ranged from 9.77 to 26.12 as a function of the process conditions under which the tucupi powder was obtained. Although the changes in color did not mean the product had lost its characteristics, it is important to point out that dramatic changes in color after some processing may lead to the product being rejected by consumers since that property is closely related to product quality (León et al. 2006). According to the ANOVA (Table 2), the linear effects of IT $\left(X_{1}\right)$, FR $\left(X_{2}\right)$, and MD $\left(\mathrm{X}_{3}\right)$, the quadratic effects of FR $\left(\mathrm{X}_{22}\right)$ and of the interaction between IT and $\mathrm{MD}\left(\mathrm{X}_{13}\right)$ were statistically significant $(p \leq 0.05)$ for the $\Delta \mathrm{E}^{*}$ response. For that response, MD (linear) was the factor with the greatest effect. The response surfaces show that an increase in MD (Fig. 2g, h) and FR (Fig. 2h) caused the $\Delta \mathrm{E}^{*}$ response to increase. In turn, this response increased with IT for the lowest MD levels, but the opposite behavior was observed for the highest MD levels (Fig. 2g). These behaviors are confirmed by the positive effects of MD and FR, and by the negative effect of IT, which can be observed the linear perturbation plots (Fig. 2i). The variations in $\Delta \mathrm{E}^{*}$ observed are attributed to the changes in product properties due to the process conditions, particularly to the addition of maltodextrin, which has white color. The products with the lowest $\Delta \mathrm{E}^{*}$ values had the characteristic yellow color of tucupi.

\section{$\beta$-carotene content}

The $\beta$-carotene content in tucupi powder ranged from 8.34 to $16.82 \mu \mathrm{g} / \mathrm{g}$ as a function of the operational conditions. Carotenoids were the main compounds responsible for tucupi's characteristic yellow color. The quadratic effects of IT $\left(\mathrm{X}_{11}\right)$, FR $\left(\mathrm{X}_{22}\right)$, and $\mathrm{MD}\left(\mathrm{X}_{33}\right)$ and of the interaction between IT and MD $\left(\mathrm{X}_{13}\right)$ were statistically significant ( $p \leq 0.05$ ), MD (quadratic) as the factor that presented the greatest effect for the $\beta$-carotene content response (Table 2). The response surfaces showed minimal points for the response in the intermediate levels of the process variables (Fig. 2j, k), which are attributed to the quadratic effects. In turn, according to the linear perturbation plot (Fig. 2l) IT and FR had negative effects and MD had a 
(a)

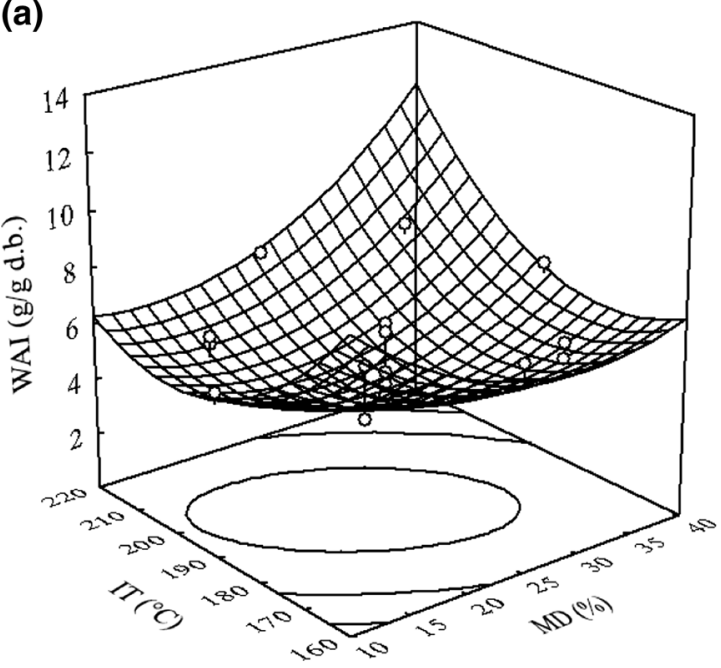

(c)

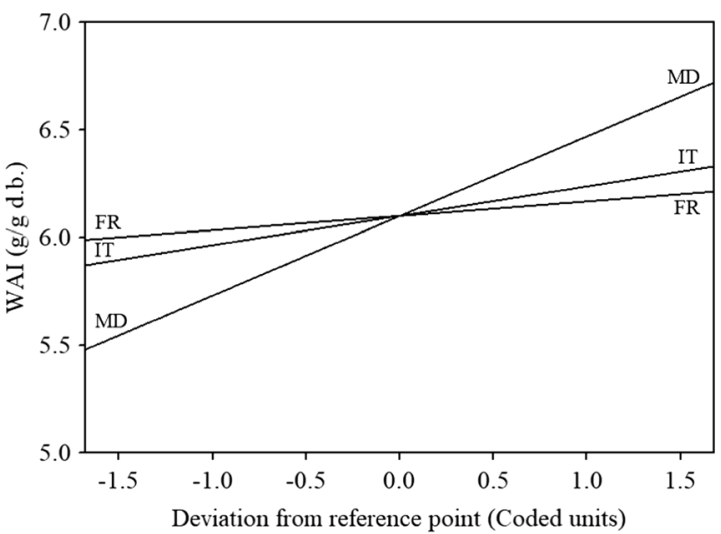

(e)

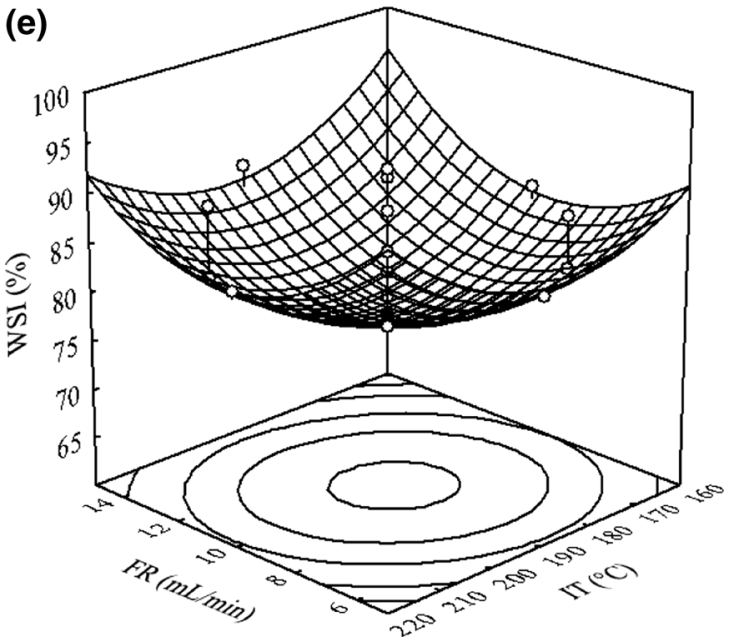

(b)

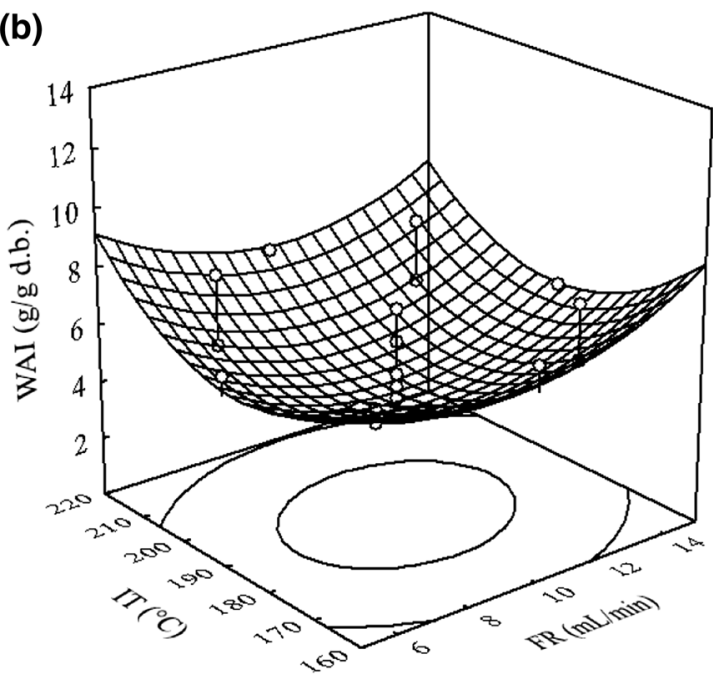

(d)

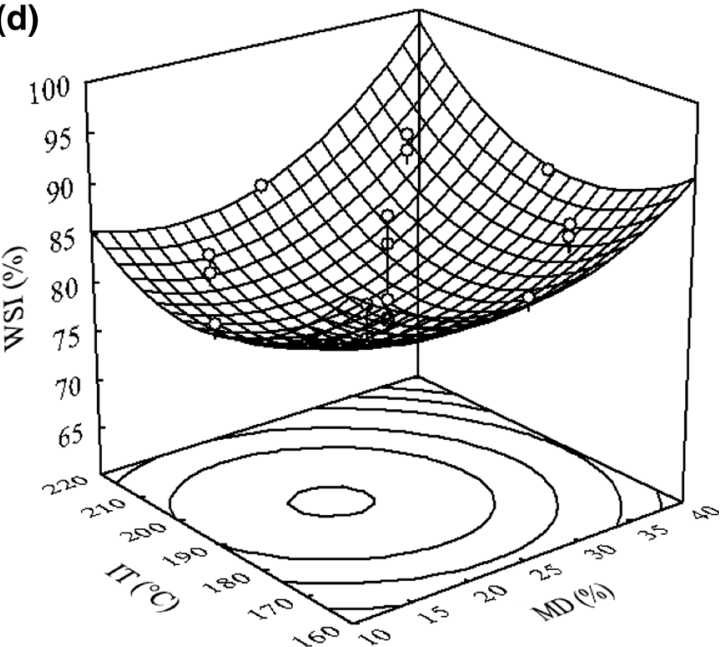

(f)

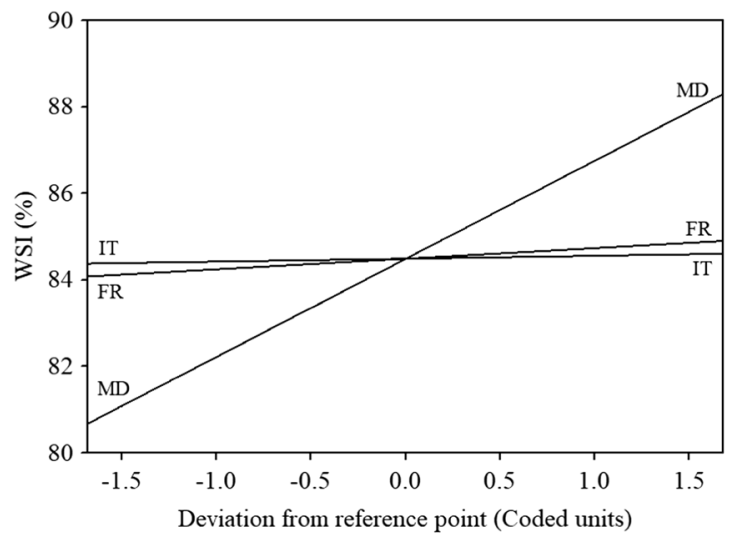

Fig. 2 Response surface and linear perturbation plots for the effects of variables on the WAI $(\mathbf{a}-\mathbf{c})$, WSI $(\mathbf{d}-\mathbf{f}), \Delta \mathrm{E}^{*}(\mathbf{g}-\mathbf{i})$ and $\beta$-carotene content $(\mathbf{j}-\mathbf{l})$. The value of the third factor was fixed at $190{ }^{\circ} \mathrm{C}$ for IT, $10 \mathrm{~mL} / \mathrm{min}$ for FR and $25 \%$ for MD 
(g)

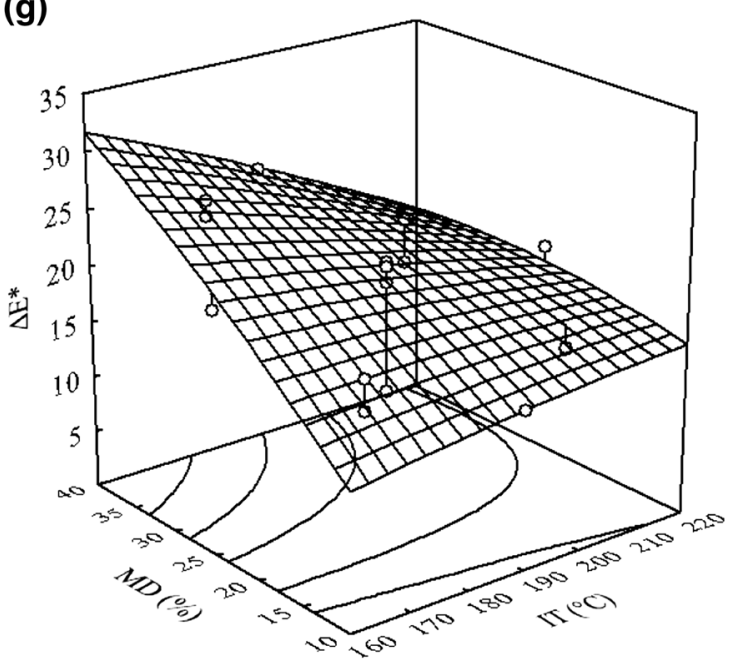

(i)
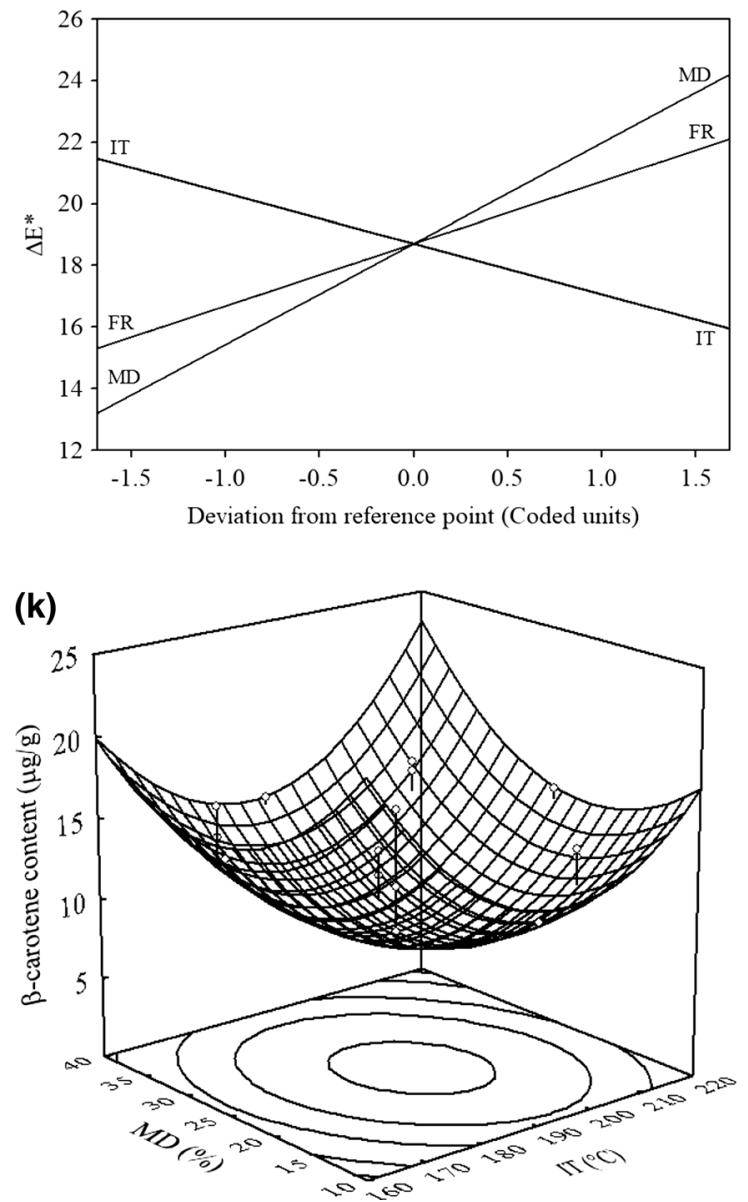

Fig. 2 continued

positive effect on $\beta$-carotene content. The reduction of $\beta$ carotene content with the increase of the IT and FR is attributed to the thermosensitive character and (h)
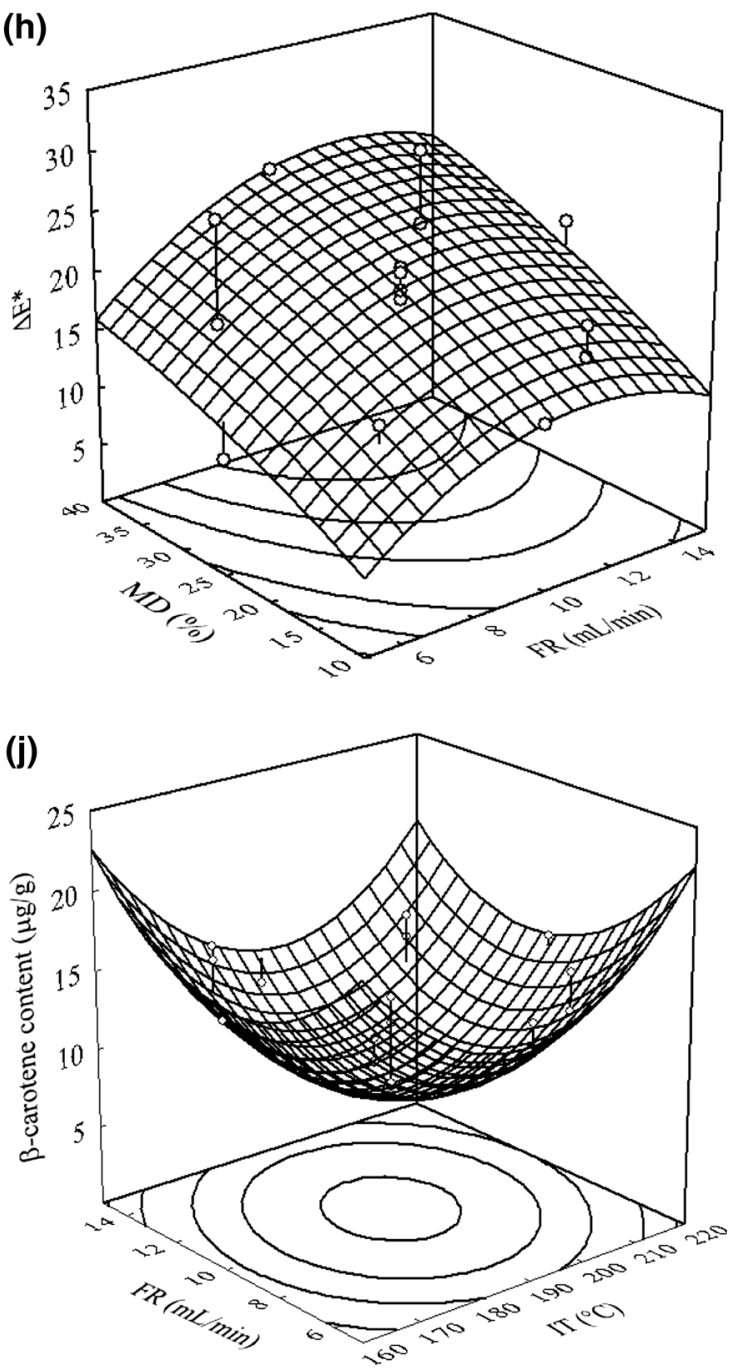

(I)

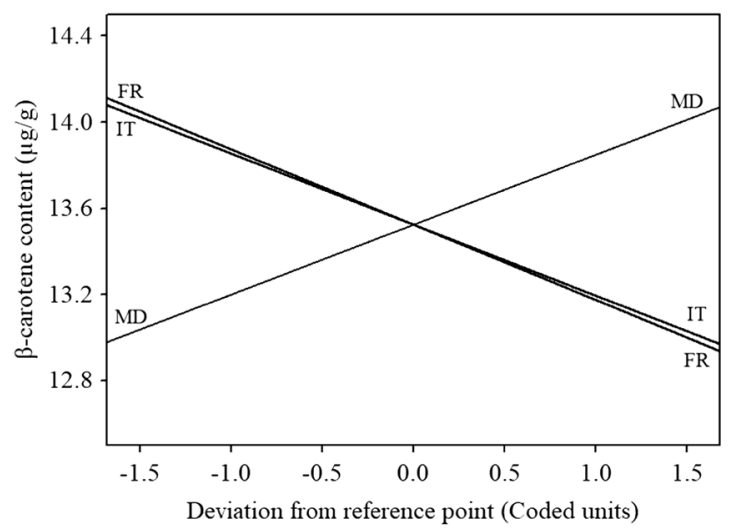

susceptibility of these pigments at oxidative process (Quek et al. 2007). For the highest levels of the variables IT and FR, the high $\beta$-carotene contents observed can be attributed 
to the increase in film formation rate on the surface of the powder particles, which creates a crust that limits the migration of material from the particle's core to its surface (Rascón et al. 2011). In turn, the increase in $\beta$-carotene content with MD confirms the efficiency of maltodextrin in preventing the breakdown of the compound.

\section{Scanning electron microscopy}

The electromicrographies of the products obtained by SEM (Fig. 3) were used to assess the influence of the drying process conditions on the morphology of tucupi powder particles. Overall, the particles were spherical and of different sizes, characteristics commonly found in products obtained by spray drying. The particle surfaces were predominantly wrinkled, although the surface of some particles was completely smooth, and all were amorphous. According to Jaya and Das (2009), the formation of amorphous particles in products obtained by spray drying can be attributed to the short drying time, which makes crystalline solids such as sugars and acids present in the product become amorphous, a state defined by the lack of molecule organization. The products obtained with the lowest MD levels (Fig. 3a, c, e, g, m) and the highest FR
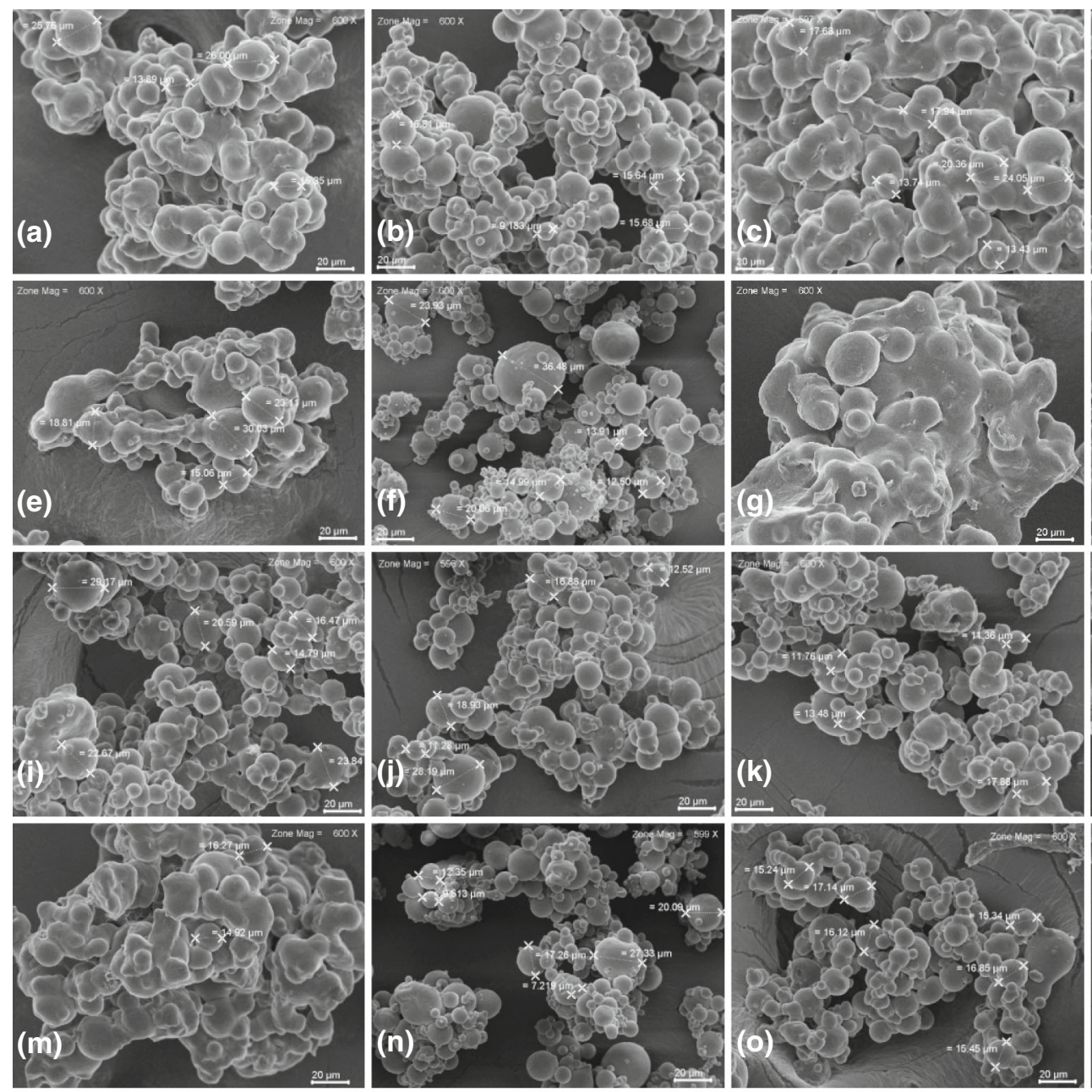
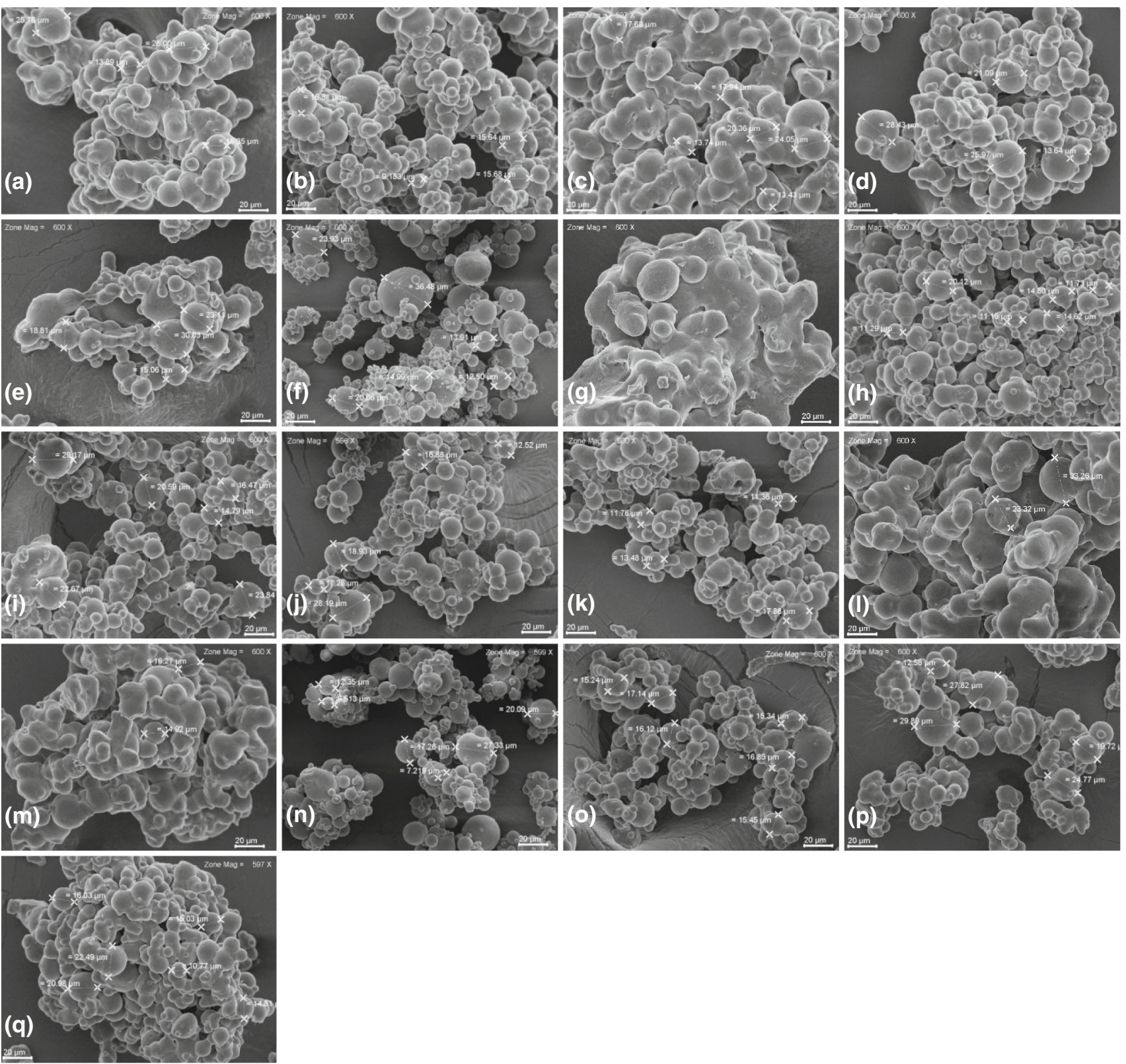

Fig. 3 Scanning electron microscopy images of the tucupi powder obtained at different spray drying process conditions. a run 1, b run 2 , $\mathbf{c}$ run 3 , $\mathbf{d}$ run $4, \mathbf{e}$ run $5, \mathbf{f}$ run $6, \mathbf{g}$ run $7, \mathbf{h}$ run $8, \mathbf{i}$ run $9, \mathbf{j}$ run $10, \mathbf{k}$ run $11, \mathbf{I}$ run $12, \mathbf{m}$ run $13, \mathbf{n}$ run $14, \mathbf{o}$ run $15, \mathbf{p}$ run $16, \mathbf{q}$ run 17 
level (Fig. 31) had more wrinkled, piled up particles with strong adherence (tackiness) and attraction among them. Those characteristics are attributed to the higher moisture retention in those products, which causes clumping and tackiness of the material produced (Goula and Adamopoulos 2010). When the intermediate MD level (Fig. 3i-l, $\mathrm{o}-\mathrm{q}$ ) and the highest MD levels (Fig. 3b, d, f, h, n) were employed, increasingly smoother particles were formed and the powders were less tacky. Tackiness is a phenomenon resulting from clumping in the drying process and is critical in industrial drying of sugar-rich products (Kudra 2003). The powders that were more even regarding shape, dispersion, and smooth and intact surfaces were obtained with the highest IT and MD levels and the lowest FR levels (Fig. 3f, j, n). A similar behavior was observed by Marques et al. (2014b), who reported that raising IT and lowering FR led to quick water evaporation, which prevented particle shrinkage and led to more even particle structure.

\section{Optimization}

Optimization refers to the improvement in performance of a process, system, or product in order to obtain maximum benefit and/or minimum cost. The spray drying process conditions for tucupi powder obtention were optimized using the desirability function. In this assessment, obtaining a product with low moisture, $\mathrm{a}_{\mathrm{w}}$, hygroscopicity, and $\Delta \mathrm{E}^{*}$ and high WAI, WSI, and $\beta$-carotene content was desirable. Therefore, based on the numerical optimization and within the conditions established, the optimal values indicated by the desirability function for the drying process were: $\mathrm{IT}=214{ }^{\circ} \mathrm{C}, \mathrm{FR}=8.67 \mathrm{~mL} / \mathrm{min}$, and $\mathrm{MD}=27 \%$ (desirability $=0.9936)$. Therefore, the values of moisture content $(9.56 \mathrm{~g} / 100 \mathrm{~g}), \mathrm{a}_{\mathrm{w}}(0.101)$, hygroscopicity (37.45\% d.b.), WAI (6.68 g/g d.b.), WSI (84.77\%), $\Delta \mathrm{E}^{*}(17.05)$ and $\beta$-carotene content $(13.72 \mu \mathrm{g} / \mathrm{g})$ were obtained in this optimal conditions.

\section{Conclusion}

This research defined the process conditions for obtaining tucupi powder by spray drying. The response surface methodology and desirability function showed that the experimental conditions studied enable obtaining tucupi powder with $9.56 \mathrm{~g} / 100 \mathrm{~g}$ moisture, 0.101 water activity, $37.45 \%$ hygroscopicity, $6.68 \mathrm{~g} / \mathrm{g}$ d.b. water absorption index, $84.77 \%$ water solubility index, 17.05 total color difference, and $13.72 \mu \mathrm{g} / \mathrm{g} \beta$-carotene content; which are desirable characteristics for the product. To that end, the spray drying process must be carried out with inlet air temperature of $214{ }^{\circ} \mathrm{C}$, feed flow rate of $8.67 \mathrm{~mL} / \mathrm{min}$, and
$27 \%$ maltodextrin must be added to the solids fraction of the tucupi suspension injected into the spray dryer. The statistical analysis showed that inlet air temperature was the variable with the greatest effect on most of the studied responses. These results indicate that good quality of tucupi powder can be obtained by spray drying, with potential applications for the food industry.

Acknowledgements The authors would like to thank CNPq (Conselho Nacional de Desenvolvimento Científico e Tecnológico) for financial support (473898/2012-8).

\section{References}

Adhikari B, Howes T, Bhandari BR, Troung V (2003) Characterization of the surface stickiness of fructose-maltodextrin solutions during drying. Dry Technol 21(1):17-34. doi:10.1081/ DRT-120017281

Adhikari B, Howes T, Bhandari BR, Troung V (2004) Effect of addition of maltodextrin on drying kinetics and tackiness of sugar and acid-rich foods during convective drying: experiments and modelling. J Food Eng 62(1):53-68. doi:10.1016/S02608774(03)00171-7

Anderson RA, Conway HF, Pfeifer VF, Griffin EL Jr (1969) Gelatinization of corn grits by roll and extrusion cooking. Cereal Sci Today 14(1):4-12

AOAC (1997) Official methods of analysis of the Association of Official Analytical Chemist. Washington

Augusto-Ruiz W, Bonato S, Arrieche L, Risso F (2003) Characterization of pregelatinized whole rice flour produced from broken rice grains. Rev Ciênc Exatas Eng 13(8):25-46

Balasubramani P, Viswanathan R, Vairamani M (2013) Response surface optimization of process variables for microencapsulation of garlic (Allium sativum L.) oleoresin by spray drying. Biosyst Eng 114(3):205-213. doi:10.1016/j.biosystemseng.2012.12.008

Barbosa-Cánovas GV, Juliano P (2005) Physical and chemical properties of food powders. In: Onwulata C (ed) Encapsulated and powdered foods. Taylor \& Francis, New York, pp 39-71

Bas D, Boyaci IH (2007) Modeling and optimization I: usability of response surface methodology. J Food Eng 78(3):836-845. doi:10.1016/j.jfoodeng.2005.11.024

Bhandari BR, Hartel RW (2005) Phase transitions during food powder production and powder stability. In: Onwulata C (ed) Encapsulated and powdered foods. Taylor \& Francis, New York, pp 261-292

Cai YZ, Corke H (2000) Production and properties of spray-dried Amaranthus betacyanin pigments. J Food Sci 65(7):1248-1252. doi:10.1111/j.1365-2621.2000.tb10273.x

Cassoni V, Cereda MP (2011) Cassava wastewater acetic fermentation process' evaluation. Rev Energy Agric 26(4):101-113. doi:10.17224/EnergAgric.2011v26n4p101-113

Chegini RG, Ghobadian B (2005) Effect of spray-drying conditions on physical properties of orange juice powder. Dry Technol 23(3):657-668. doi:10.1081/DRT-200054161

Chen Q, Bi J, Zhou Y, Liu X, Wu X, Chen R (2014) Multi-objective optimization of spray drying of jujube (Zizyphus jujuba Miller) powder using response surface methodology. Food Bioprocess Technol 7(6):1807-1818. doi:10.1007/s11947-013-1171-z

Chisté RC, Cohen KO (2011) Total and free cyanide contents determination during the processing steps for preparing tucupi. Rev Inst Adolfo Lutz 70(1):41-46 
Desai KGH, Park HJ (2005) Recent developments in microencapsulation of food ingredients. Dry Technol 23(7):1361-1394. doi:10.1081/DRT-200063478

Fennema OR (1996) Food chemistry. Marcel Dekker, New York

Goula AM, Adamopoulos KG (2010) A new technique for spray drying Orange juice concentrate. Innov Food Sci Emerg Technol 11(1):342-351. doi:10.1016/j.ifset.2009.12.001

Granato D, Calado VMA (2014) The use and importance of design of experiments (DOE) in process modelling in food science and technology. In: Granato D, Calado VMA (eds) Mathematical and statistical methods in food science and technology, 1st edn. Wiley, Blackwell, New York, pp 1-18

Homma AKO, Santos JC, Sena ALS, Menezes AJEA (2014) Smallholder production in the Amazon: conflicts and opportunities, which ways? Amaz Ciênc Desenvolv 9(18):137-154

Jaya S, Das H (2004) Effect of maltodextrin, glycerol monostearate and tricalcium phosphate on vacuum dried mango powders properties. J Food Eng 63(2):125-134. doi:10.1016/S02608774(03)00135-3

Jaya S, Das H (2009) Glass transition and tacky point temperature and stability/mobility diagram of fruits powder. Food Bioprocess Technol 2(1):1-7. doi:10.1007/s11947-007-0047-5

Kha TC, Nguyen MH, Roach PD (2010) Effect of spray drying conditions on the physicochemical and antioxidant properties of the Gac (Momordica cochinchinensis) fruit aril powder. J Food Eng 98(3):385-392. doi:10.1016/j.jfoodeng.2010.01.016

Kudra T (2003) Tacky region in drying - definition and identification. Dry Technol 21(8):1457-1469. doi:10.1081/DRT-120024678

Kurozawa LE, Morassi AG, Vanzo AA, Park KJ, Hubinger MD (2009) Influence of spray drying conditions on physicochemical properties of chicken meat powder. Dry Technol 27(11):1248-1257. doi:10.1080/07373930903267187

León K, Mery D, Pedreschi F, León J (2006) Color measurement in $\mathrm{L}^{*} \mathrm{a}^{*} \mathrm{~b}^{*}$ units from RGB digital images. Food Res Int 39(10):1084-1091. doi:10.1016/j.foodres.2006.03.006

Marques GR, Borges SV, Botrel DA, Costa JMG, Silva EK, Corrêa JLG (2014a) Spray drying of green corn pulp. Dry Technol 32(7):861-868. doi:10.1080/07373937.2013.873452

Marques GR, Borges SV, Mendonça KS, Fernandes RVB, Menezes EGT (2014b) Application of maltodextrin in green corn extract powder production. Powder Technol 263:89-95. doi:10.1016/j. powtec.2014.05.001

Montgomery DC (2001) Desing and analysis of experiments. Wiley, New York
Myers RH, Montgomery DC (2002) Response surface methodology: process and product optimization using designed experiments. Wiley, New York

Nelson DL, Cox MM (2012) Lehninger-principles of biochemistry. Freeman, New York

Noordin MY, Venkatesh VV, Sharif S, Elting S, Abdullah A (2004) Application of response surface methodology in describing the performance of coated carbide tools when turning AISI 1045 steel. J Mater Process Technol 145(1):46-58. doi:10.1016/ S0924-0136(03)00861-6

Obon JM, Castellar MR, Alacid M, Fernández-López JA (2009) Production of a red-purple food colorant from Opuntia stricta fruits by spray drying and its application in food model systems. J Food Eng 90(4):471-479. doi:10.1016/j.jfoodeng.2008.07.013

Quek SY, Chok NK, Swedlund P (2007) The physicochemical properties of spray-dried watermelon powders. Chem Eng Process 46(5):386-392. doi:10.1016/j.cep.2006.06.020

Rascón MP, Beristain C, Garcia H, Salgado M (2011) Carotenoid retention and storage stability of spray-dried encapsulated paprika oleoresin using gum Arabic and Soy protein isolate as wall materials. Food Sci Technol 44(2):549-557. doi:10.1016/j. lwt.2010.08.021

Ré M (1998) Microencapsulation by spray drying. Dry Technol 16(6):1195-1236. doi:10.1080/07373939808917460

Rodriguez-Amaya DB, Kimura M (2004) Harvestplus handbook for carotenoid analysis. Washington

Rodríguez-Jimenes GC, Páramo-Calderón DE, Wall-Martínez HA, Robles-Olvera VJ, Valerio-Alfaro G, García-Alvarado MA (2014) Effect of process variables on spray-dried garlic juice quality evaluated by multivariate statistic. Food Bioprocess Technol 7(8):2434-2442. doi:10.1007/s11947-014-1311-0

Sagar VR, Suresh Kumar P (2010) Recent advances in drying and dehydration of fruits and vegetables: a a review. J Food Sci Technol 47(1):15-26. doi:10.1007/s13197-010-0010-8

Tonon RV, Brabet C, Hubinger MD (2009) Influence of drying air temperature and carrier agent concentration on the physicochemical properties of açai juice powder. Ciênc Technol Aliment 29(2):444-450. doi:10.1590/S0101-2061200900020 0034

Yousefi S, Emam-Djomeh Z, Mousavi MS (2011) Effect of carrier type and spray drying on the physicochemical properties of powdered and reconstituted pomegranate juice (Punica Granatum L.). J Food Sci Technol 48(6):677-684. doi:10.1007/s13197010-0195-x 